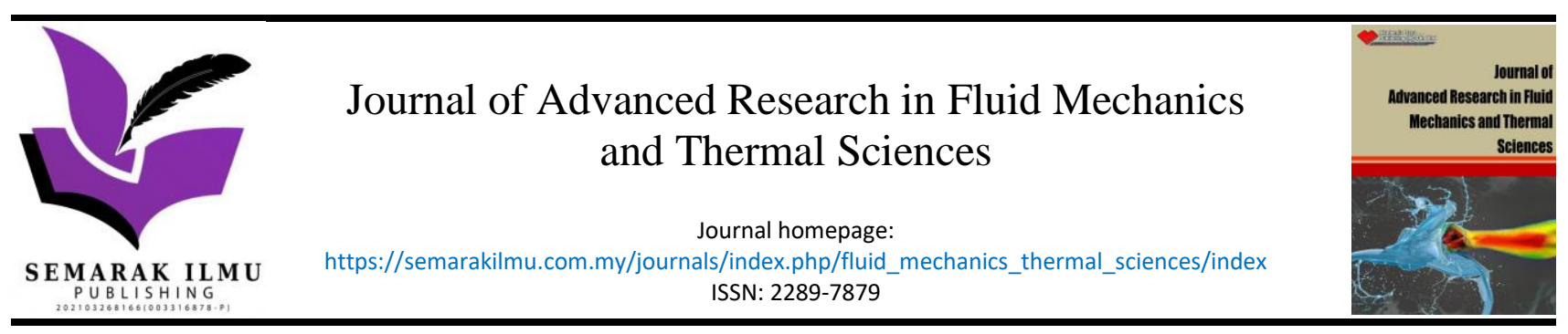

\title{
Energy Efficiency Initiatives for A Hospital Building in Malaysia
}

\author{
Mohamad Saiful Islam Aziz ${ }^{1}$, Hasbullah Harun², Ahmad Shahril Izham Ramli², Azlin Mohd Azmi ${ }^{1,4,}{ }^{*}$, \\ Nofri Yenita Dahlan ${ }^{3,4}$, Ramlan Zailani ${ }^{1,4}$

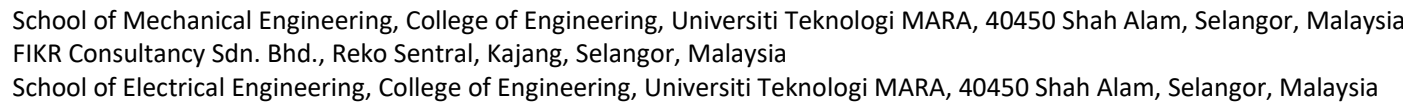

\section{Article history:}

Received 28 July 2021

Received in revised form 10 October 2021

Accepted 21 October 2021

Available online 13 November 2021

\section{Keywords:}

Hospital; energy efficiency; energy

management

\begin{abstract}
In the past decades, research about energy consumption reduction has become a trend due to concern of energy wastage that leads to the negative impact on the environment. Commercial sector produces higher energy consumption compared to other sectors in Malaysia and hospital building is one of the highest energy consumptions in the commercial sector. Continuous operation time and complexity of engineering system are some of the reasons for high energy consumptions in hospital buildings that leads to high energy costs. This study examines the electricity load apportioning for a hospital building in Selangor, Malaysia through a detailed energy audit. From the energy audit, several Energy Efficiency Initiatives (EEI) were identified in reducing the energy usage in hospital: room temperature control, efficient lighting system, efficient unit for Air-Conditioning Split Unit (ACSU) and Variable Speed Drive (VSD) installation. The EEls is expected to produce a total electricity saving of 1,250,692 kWh/year, equivalent to a cost saving of RM 421, 706/year and total emission reduction of 869 tonnes $\mathrm{CO}_{2}$ per year.
\end{abstract}

\section{Introduction}

In Malaysia, electricity generation comes from three different sources, namely coal, natural gas and hydro [1]. In 2019, Tenaga Nasional Berhad (TNB) as the main electricity provider in Malaysia reported that $53.90 \%$ of total electricity generation in Malaysia comes from coal, while $42.30 \%$ of total generation comes from natural gas, 3.10\% comes from hydro, and $0.60 \%$ comes from solar [2]. From this statistic, the electricity generation were heavily dependent on coal and natural gas and this substantial dependence on both sources raised a concern. TNB power plants have produced 60 million tons of $\mathrm{CO}_{2}$, which approximately $32 \%$ of total emission produced in 2015 , and these numbers has increased from year to year due to the shift of power generation using gas to coal [3].

In the past several years, total electricity consumption in Malaysia has shown an increasing pattern where consumption increased from 94,666 GWh in 2010 to 116,273 GWh in 2017 contributing to an increment of an average $3.26 \%$ per year [4]. Total energy consumption by the

\footnotetext{
* Corresponding author.

E-mail address: azlinazmi@uitm.edu.my

https://doi.org/10.37934/arfmts.88.3.145155
} 
commercial sector in Malaysia was approximately 30 to $32 \%$ from the total energy consumption in all sectors [5,6]. The total amount of energy used in commercial sector in Malaysia has risen from 2003 Petajoules (PJ) to 2526 PJ within the period from 2000 to 2005 and reached 3127.7 PJ in 2010 [7].

Global warning due to increasing carbon emission and depletion of fossil fuel are some of the factors that contribute to the increasing number of demands for building energy efficiency project implementation. Due to this facts, energy efficiency initiatives (EEI) projects for energy consumption reduction become a priority and realistically become a solution to reduce the gap between the energy consumption and environment issues [8,9]. In addition, energy consumption study in hospital buildings is scarce in literature and energy consumption pattern would be different according to different hospital category. This study focuses on observing the electricity consumption situation of a hospital building in Malaysia. From the study outcome, actual electricity load apportioning in a selected hospital building is revealed and suitable initiatives for the electricity consumption reduction can be planned.

\subsection{Energy Efficiency Scenario in Malaysia}

Carbon emission reduction has become one of the main priorities for Malaysia to combat the global warming In the United Nations Framework Convention on Climate Change's (UNFCCC) $15^{\text {th }}$ Conference of Parties (COP 15) in 2009, Malaysia was committed to produce $40 \%$ reduction of total GDP emission intensity based on 2005 level by 2020 and later during $21^{\text {st }}$ Conference of Parties (COP21) in 2015, Malaysia once again showed commitment in reducing greenhouse gas emission by $45 \%$ by $2030[10,11]$.

Internally, Malaysia Government through the then-Ministry of Energy, Green Technology and Water has implemented various environment-based initiatives in the management and financial aspect, such as the introduction of National Green Technology Policy in 2019 [12], Green Government Procurement (GGP) and MyHIJAU as guideline for green product purchasing in government agencies [13].

\subsection{Previous Studies about Energy Efficiency at Hospital Buildings}

In the past decades, energy efficiency at hospital building become a trending subject among researchers worldwide. The complexity of the hospital building which encompasses various engineering system as well as healthcare building operation nature is highly challenging to implement energy efficiency strategies without jeopardizing the hospital operation. Most of the strategies come in the form of engineering approaches such as improvement of heating, ventilation and airconditioning (HVAC) system, much efficient lighting system, and other aspects like building orientation and operation and maintenance (O\&M) management. Table 1 shows the existing studies on energy efficiency initiatives implementation at hospital buildings around the world. 


\section{Table 1}

Existing studies on energy efficiency initiatives implementation at hospital buildings around the world

\begin{tabular}{|c|c|c|c|c|}
\hline $\begin{array}{l}\text { Type of } \\
\text { system }\end{array}$ & Energy Efficiency Initiatives & Reference & Location & Year \\
\hline \multirow{9}{*}{$\begin{array}{l}\text { Air- } \\
\text { conditioning } \\
\text { (HVAC) }\end{array}$} & Chiller replacement with higher COP & E. Cordo, A. Campos [14] & Portugal & 2011 \\
\hline & \multirow[t]{2}{*}{$\begin{array}{l}\text { Time-programmable regulation for } \mathrm{AHU} \\
\text { system }\end{array}$} & $\begin{array}{l}\text { A. Buonomano, F. Calise et al., } \\
\text { [15] }\end{array}$ & Italy & 2014 \\
\hline & & S. Reddy, S. Sandbhor [16] & India & 2019 \\
\hline & Efficient motor for AHU system & M. Dezfouli, M. Yazid [17] & Malaysia & 2018 \\
\hline & Variable Speed Drive (VSD) installation & A. Teke, O. Timur [18] & Turkey & 2014 \\
\hline & \multirow[t]{2}{*}{ at HVAC system } & M. Dezfouli, M. Yazid [17] & Malaysia & 2018 \\
\hline & & S. Reddy, S. Sandbhor [16] & India & 2019 \\
\hline & Intelligent logical mechanism for HVAC & A. Gatea, M. Batcha [19] & Malaysia & 2020 \\
\hline & Controlling water flow for chiller system & A. Prasetyadi [20] & Thailand & 2020 \\
\hline \multirow[t]{14}{*}{ Lighting } & \multirow[t]{9}{*}{ LED Retrofitting } & E. Cordo, A. Campos[14] & Portugal & 2011 \\
\hline & & U.S. Department of Energy [21] & U.S & 2011 \\
\hline & & S. Alzubaidi, S. Poori [22] & Qatar & 2012 \\
\hline & & A. Radwan, A. Hanafy [23] & Egypt & 2016 \\
\hline & & G. Patil, V. Kamath [24] & India & 2018 \\
\hline & & M. William, A. El-Haridi [25] & Egypt & 2019 \\
\hline & & S. Reddy, S. Sandbhor [16] & India & 2019 \\
\hline & & D. Suszanowicz, P. Ratuszny [26] & Poland & 2019 \\
\hline & & D. Hyseni, D. Tashevski [27] & Kosovo & 2020 \\
\hline & \multirow{4}{*}{$\begin{array}{l}\text { Motion and control sensor for lighting } \\
\text { control }\end{array}$} & E. Cordo, A. Campos [14] & Portugal & 2011 \\
\hline & & U.S. Department of Energy [21] & U.S & 2011 \\
\hline & & A. Gatea, M. Batcha [19] & Malaysia & 2020 \\
\hline & & S. Cesari, P. Valdiserri [28] & Italy & 2020 \\
\hline & Daylighting optimization & U.S. Department of Energy [21] & U.S & 2011 \\
\hline Boiler & PID controller installation & J. Fraile, J. San-Jose [29] & Spain & 2014 \\
\hline \multirow[t]{8}{*}{ Others } & $\begin{array}{l}\text { Electronic speed variator and control } \\
\text { system for lift system }\end{array}$ & E. Cordo, A. Campos [14] & Portugal & 2011 \\
\hline & \multirow{4}{*}{$\begin{array}{l}\text { Thermal insulation at external walls and } \\
\text { roof }\end{array}$} & A. Radwan, A. Hanafy $[23,25]$ & Egypt & 2016 \\
\hline & & M. William, A. El-Haridi [25] & Egypt & 2019 \\
\hline & & $\begin{array}{l}\text { J. Garcia-Sanz-Calcedo, A. Al-Kassir } \\
\text { [30] }\end{array}$ & Spain & 2018 \\
\hline & & D. Hyseni, D. Tashevski [27] & Kosovo & 2020 \\
\hline & \multirow[t]{3}{*}{ Efficient maintenance operations } & B. Nourdine et al., [31] & Morocco & 2019 \\
\hline & & $\begin{array}{l}\text { J. Garcia-Sanz-Calcedo, A. Al-Kassir } \\
\text { [30] }\end{array}$ & Spain & 2018 \\
\hline & & M. Gomez-Chaparro et al., [32] & Spain & 2018 \\
\hline
\end{tabular}

\section{Methodology}

A public hospital in state of Selangor, Malaysia was selected as a case study. This hospital was selected due to its excessive electricity consumption exceeding 3,000,000 kWh over six consecutive months, which falls under the Efficient Management of Electrical Energy Regulation (EMEER) 2008 from Energy Commission of Malaysia [33].

This hospital is categorized as a major specialist hospital since it is among the few referenced hospitals in Malaysia and due to this specialized operation, this hospital consumes higher electricity consumptions compared to other hospitals. A preliminary study was conducted at the hospital to identify the load apportioning within the building. Results from the preliminary study was then used to identify the energy efficiency initiatives (EEI) suitable to be implemented at the hospital building. The framework design of this study includes data collection, data analysis and outcome presentation is illustrated in Figure 1. 


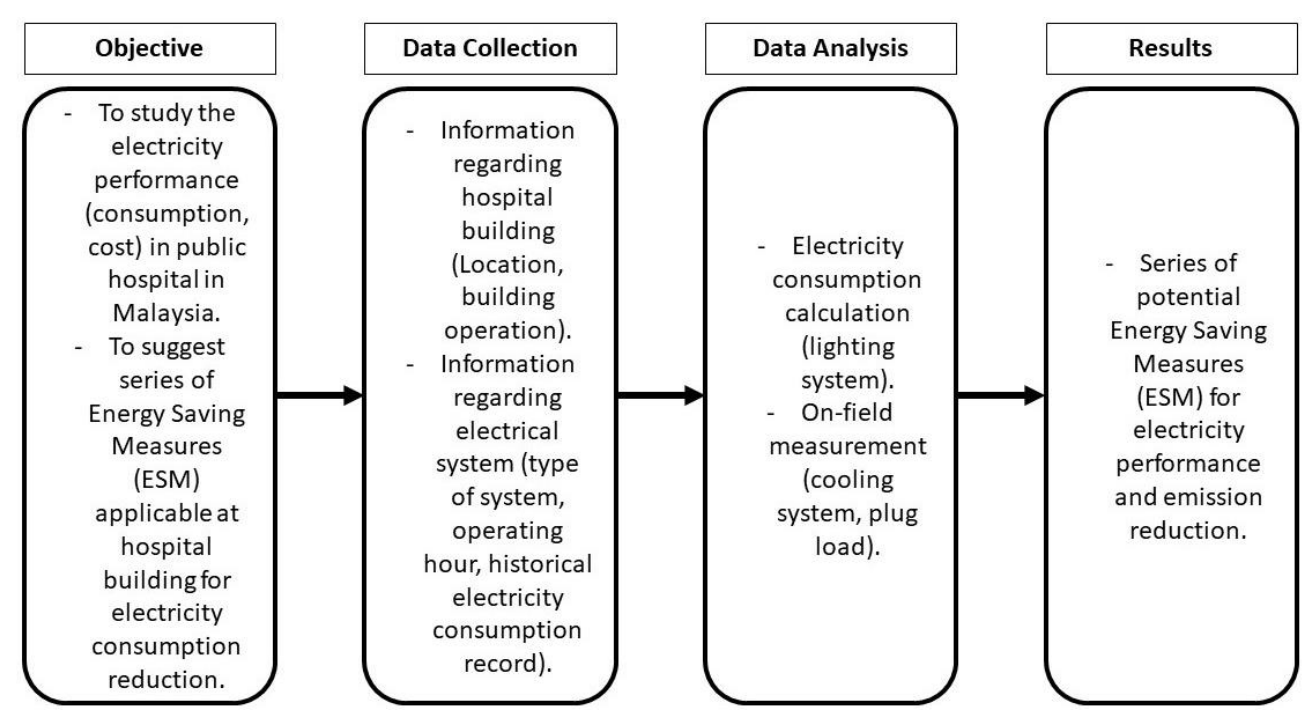

Fig. 1. Framework design of the study

\subsection{Data Collection: Energy Audit}

Energy audit is defined as a process of information collection regarding where and how much energy being used and initiatives that are applicable for energy consumption and energy cost reduction [34]. The main objective from an energy audit is to reduce energy consumptions without jeopardizing operation and comfort of the building. Basically, energy audit procedure can be split into two categories, namely preliminary energy audit and detailed energy audit. Preliminary energy audit or commonly known as a walk-through audit is a process of defining and establishing an overall energy consumption and energy saving potential through visual inspection only with assistance from certain documentations such as operation and maintenance (O\&M) records and technical reports. Establishment of achievable saving from potential EEIs mostly comes from the calculation process. Meanwhile, detailed energy audit is more complex than preliminary audit as detailed energy audit provides comprehensive energy analysis regarding current and past energy performance and identification of various potential EEIs. There are four (4) main processes in detailed energy audit: (i) information collection, (ii) load apportioning from systems, (iii) list of suitable EEls and, (iv) reporting and presentation. Figure 2 shows the process of preliminary energy audit while Figure 3 shows the process of detailed energy audit.

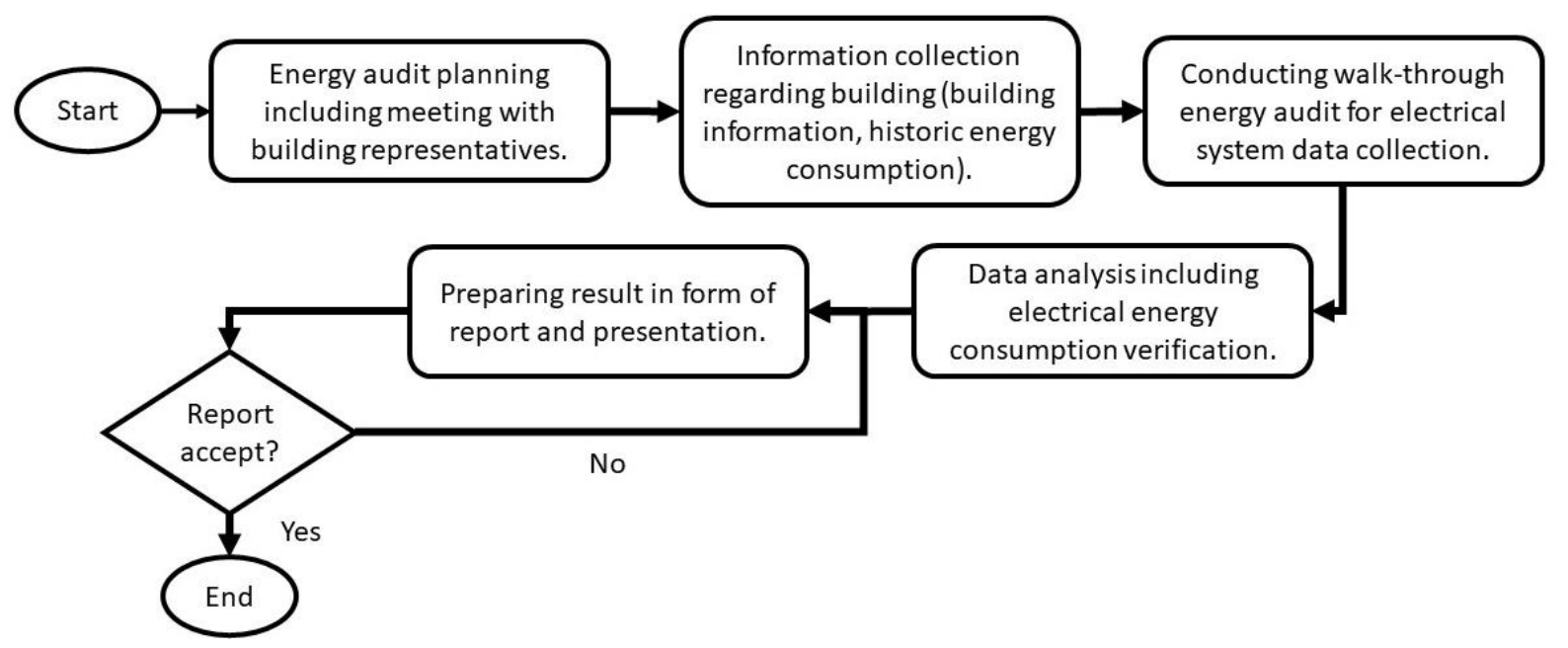

Fig. 2. Preliminary energy audit flowchart [35] 


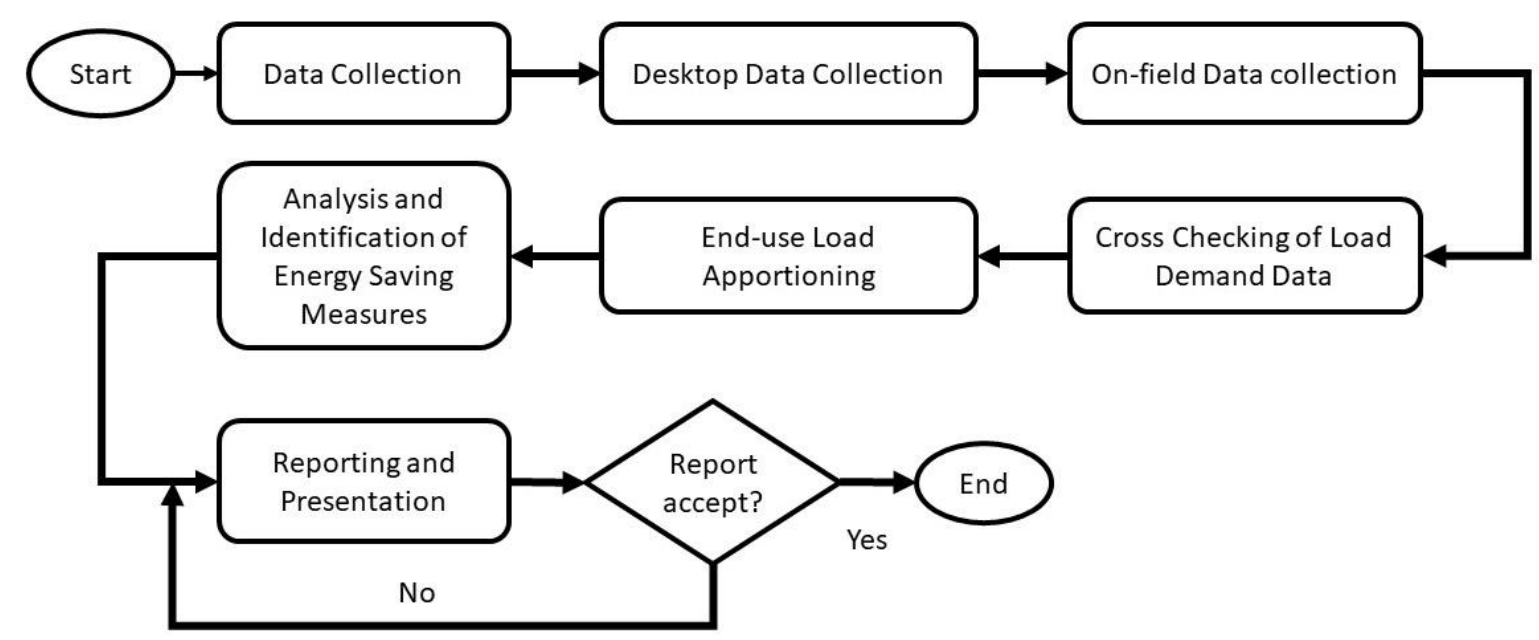

Fig. 3. Detailed energy audit flowchart [34]

\subsection{Defining the Electricity Consumption}

Since this study involves detailed energy audit for defining potential EEls in the hospital building, the total electricity consumption was based on both calculation and on-field measurement. Firstly, technical specification data of each related system was collected through desktop study and field collection method.

For electricity consumption through calculation method, only lighting system was applicable while electricity consumption for other systems such as air-conditioning system and office and hospital equipment was defined from on-field measurement using data logger meter. Equation for electricity consumption for lighting system, ECLighting is shown in Eq. (1) below

ECLighting $=L T \times$ Nos $\times T D \times N D / 1000$

where ECLighting is measured in kWh, $L T$ is type of lighting bulb in Watt (W), Nos is lighting tube numbers, $T D$ is operation time per day in hour $(\mathrm{h})$ and $N D$ is total number of days within a month or year [9]. For this study, assumption was made where total days in a month is defined as 30 days while total days per year is 365 days.

\section{Results}

\subsection{Electricity Load Apportioning}

Total electricity load apportioning after detailed energy audit conducted in 2020 is shown in Figure 4. There are five (5) different categories for electric load apportioning namely cooling system, lighting system, plug load, electric boiler and others including server room, lift motor, pump system and sewage treatment plant. 


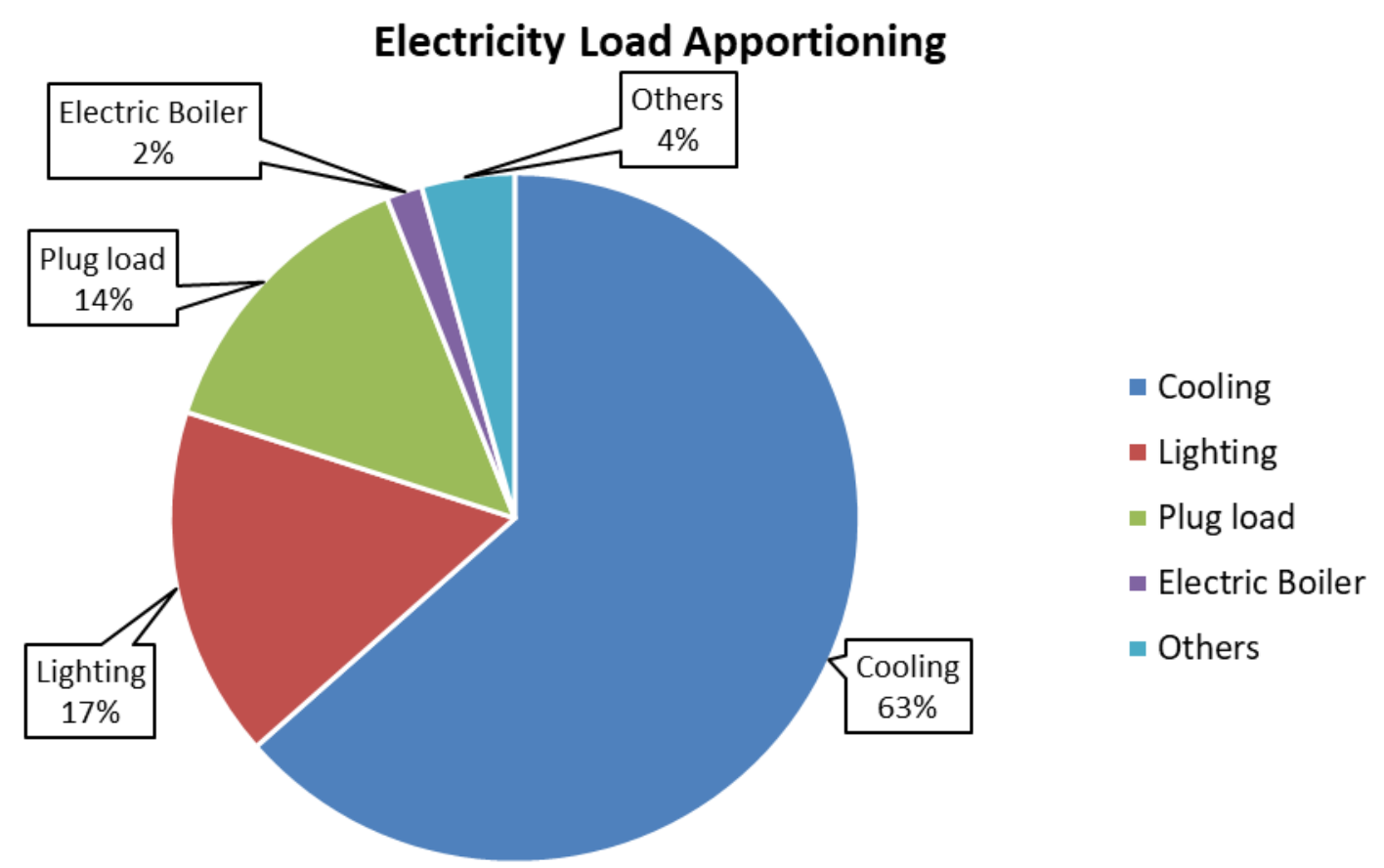

Fig. 4. Electricity Load Apportioning based on Detailed Energy Audit in 2020

Based on the electricity load apportioning in Figure 4, cooling system has the largest contribution at $64.57 \%$ from total electricity consumption of the building, followed by the lighting system (16.78 $\%)$, plug (14.21 \%) and other system (4.44\%). Electrical boiler produces the smallest load apportioning, contributes only $1.71 \%$ from total electric consumption. This electricity load apportioning for hospital building is quite similar with other hospital buildings in Malaysia [9] and country in the tropics such as those in Thailand [36,37].

From the result of the detailed energy audit, some findings and conclusion have been identified. Firstly, the main reason cooling system was the highest in electricity consumption is due to the large number of cooling equipment such as Air-Handling Unit (AHU), Fan Coil Unit (FCU) and Airconditioning Split Unit (ACSU) in hospital buildings compared to other commercial buildings. Furthermore, hospital building operates continuously throughout the day and week, requiring not just continuous comfort level for patient and hospital staff but also optimum medical equipment operations and performance.

In addition, total electricity consumption from plug load is almost the same as lighting system due to existing numbers of high-consumption medical equipment usually used in Radiology Department such as Magnetic Resonance Imaging (MRI) and Computed Tomography (CT) scan. Heating-based equipment such as warmer and mini electric boiler used for sterilization process also operates using plug-point.

\subsection{Total Electricity Cost}

The electricity source for this hospital building is provided by Tenaga Nasional Berhad (TNB) where this hospital building is subjected to a Tariff C2 known as medium voltage peak and off-peak, a tariff usually used in commercial buildings [38]. For this tariff, cost for each kWh consumed during peak hour starting from 8.00 a.m. to 10.00 p.m. is different from cost of each kWh consumed during off-peak hour starting from 10.00 p.m. to 8.00 a.m. Meanwhile, the maximum demand (in kW) recorded in the billing period is subjected to a certain charge where the duration of maximum demand is calculated during peak hour period. 
In this study, total electricity cost is taken directly from TNB bill and the final cost in the TNB billing varies, depending on these factors; (i) total electric consumption in kWh during on-peak and off-peak for the whole billing duration, (ii) highest maximum demand in $\mathrm{kW}$ recorded during the billing period and, (iii) additional charge such as Imbalance Cost Pass-Through (ICPT) and Renewable Energy (RE) Fund. For this building, average annual electricity cost for the past 3 years is RM 8,599,122.56 per year.

\section{Energy Efficiency Initiatives (EEls)}

As mentioned in section 2.1, final process in both preliminary and detailed energy audit is identification of potential activities that are suitable to be implemented for electricity reduction purpose. These potential electricity reduction activities are known as energy efficiency initiatives (EEI). Basically, EEI can be categorised into no-cost measures, mid-cost measures and high-cost measures. In this subtopic, all three categories are presented briefly.

\subsection{EEI 1: Increase Temperature at Cool Areas}

Based on the MS 1525 standard, the recommended temperature for room and area other than Operation Theatre (OT) is $24^{\circ} \mathrm{C}$ and based on the result of the energy audit, the hospital building recorded rooms and areas of temperature lower than the recommended standard level, therefore use more electricity than expected [39]. The only solution to overcome this situation is to increase the temperature at identified area/places.

By setting all the identified area with the recommended temperature, the electricity consumption will be reduced up to $5 \%$, which is equivalent to the total electricity cost saving of RM 138,527.96 per year with immediate effect since no investment is required for this activity. Feedback from the enduser is necessary for this EEI activity so that the comfort level for end-user after EEI implementation is acceptable.

\subsection{EEI 2: Efficient Lighting System}

Most of the hospital buildings with building age of more than 10 years are still using non-efficient bulb for the lighting system. There are 3 common types of lighting bulb :4-feet T8 lamp, 2-feet T8 lamp and PLC downlight lamp. For the past several years, light emitting diode (LED) has become the main choice for energy-efficient lighting bulb as LED lighting is $90 \%$ more efficient compared to incandescent light bulbs.

In addition, LED lighting is known to have a much higher lifetime compared to incandescent light bulb where typically, the brightness of LED will dim slowly over time[40]. From this EEI activity, total electricity consumption of lighting system is expected to reduce around 626,304.96 kWh per year, contributing to electricity cost reduction of RM 228,601.31 per year with a payback period of almost 2 years.

\subsection{EEI 3: Efficient Unit for ACSU}

The air-conditioning split unit (ACSU) is usually used in wards and IT server room where both areas are operating at nearly 24 hours per day. Based on the field investigation report, most of the ACSU installed in this building is inefficient with the coefficient of performance (COP) of the sampled 
ACSU has dropped (between 0.18 to 2.0 ) compared to the minimum COP requirement by MS 1525 standard (recommended COP: 3.0).

From this situation, it is highly recommended to replace these ACSU with energy efficient ACSU. Based on Government Green Procurement (GGP), it is encourage for building owner to choose a 5Star rating for ACSU which guarantees its energy-efficient performance [41]. With the expected annual electricity saving of $86,346 \mathrm{kWh}$ equivalent to cost saving of RM $26,443.60$ and a low payback period ( 1 year), this EEl is suitable to be implemented in hospital buildings which heavily depending on ACSUs for their cooling system.

\subsection{EEI 4: Variable Speed Drive (VSD) Installation}

During the early stages of the building construction, engineers tend to over-size the airconditioning system design which over supplies air to user areas. Therefore, to overcome the oversupply, the damper is needed to restrict the air flow.

As the technology advanced from time to time, solid-state device, namely Variable Speed Drive (VSD) is suitable to overcome this problem. With VSD regulates speed of Air Handling Unit (AHU) motor, air supply from AHU can be matched with demand. Estimated electricity savings when the AHU fan motor is equipped with a VSD can be up to $85,704.40 \mathrm{kWh}$ per year with the estimated electricity cost saving of RM 28,143.04 per year.

\section{Electricity Performance Saving and Emission Reduction}

By implementing all the identified EEls discussed in previous section, the total electricity consumption can be reduced up to $4.90 \%$ (an electricity saving of 1,250,692.09 kWh per year) which is equivalent to a cost saving of RM 421,715.93 per year. Meanwhile, the total emission reduction from this EEls is equal to 867.98 tonne $\mathrm{CO}_{2}$ per year. The saving summary of recommended EEls implementation is shown in Table 2.

\section{Table 2}

Saving summary from recommended EEIs

\begin{tabular}{llllll}
\hline EEls & $\begin{array}{l}\text { Electricity consumption } \\
\text { saving (kWh/year) }\end{array}$ & $\begin{array}{l}\text { Electricity cost } \\
\text { saving (RM/year) }\end{array}$ & $\begin{array}{l}\text { Emission } \\
\text { reduction (ton } \\
\mathrm{CO}_{2} / \text { year) }\end{array}$ & $\begin{array}{l}\text { Estimation Cost } \\
\text { investment (RM) }\end{array}$ & $\begin{array}{l}\text { Simple Payback } \\
\text { Period (year) }\end{array}$ \\
\hline EEI 1 & $452,336.20$ & $138,527.96$ & 313.92 & 0.00 & 0.00 \\
EEI 2 & $626,304.96$ & $228,601.31$ & 434.66 & $397,200.00$ & 1.74 \\
EEI 3 & $86,346.53$ & $26,443.62$ & 59.92 & $27,400.00$ & 1.04 \\
EEI 4 & $85,704.40$ & $28,143.04$ & 59.48 & $324,006.65$ & 11.51 \\
TOTAL & $1,250,692.09$ & $421,715.93$ & 867.98 & $748,606.65$ & 1.78 \\
\hline
\end{tabular}

Although all the recommended EEls listed in Table 2 above are promising in reducing electricity in the hospital building, large investment cost is required to implement the EEls. Therefore, financial constraint will be the main barrier for energy-efficient adoption at hospital buildings. The best strategy for adopting energy-efficient initiatives in hospital building is prioritized using the no-cost measures, with consideration of implementing the mid-cost and high-cost measures subject to financial availability. 


\section{Conclusion}

With the annual electricity bill of around RM 8,599,122.56 per year, a series of potential EEI initiatives were introduced for reducing the electrical energy consumption in a public hospital building in Selangor, Malaysia. There were four identified potential EEI initiatives that would reduce the total annual electricity consumption and cost of up to $4.90 \%$ equivalent to $1,250,692.09 \mathrm{kWh}$ savings and RM 421,715.93 saving per year. Estimated total investment cost stands at RM 748,606.65 with an estimated payback period of 1.78 years. Total emission reduction is projected to be 867.98 tonne $\mathrm{CO}_{2}$ per year. It is expected that through these initiatives, the reduction target in electricity consumption of at least $1 \%$ annually can be achieved, in line with the hospital management's objective. At the same time, these also support the Sustainability Program by the Ministry of Health Malaysia and contribute to reducing greenhouse gas emission from the building sector.

\section{Acknowledgements}

Authors would like to acknowledge assistance given by FIKR Consultancy Sdn. Bhd as the main consultant for the detailed energy audit assessment and Universiti Teknologi MARA for the 600RMC/MYRA 5/3/LESTARI (050/2020) MyRA grant.

\section{References}

[1] Khattak, M. A., A. Arif, A. Hannan, F. Syukri, and H. Hamid. "Design and planning of a nuclear power plant in Malaysia: A feasibility report." Journal of Advanced Research in Applied Sciences and Engineering Technology 3, no. 1 (2016): 67-76.

[2] Tenaga Nasional Berhad. "Annual Report 2019." 2018.

[3] Shamsuddin, Abd Halim. "Development of renewable energy in Malaysia-strategic initiatives for carbon reduction in the power generation sector." Procedia Engineering $49 \quad$ (2012): $384-391$. https://doi.org/10.1016/j.proeng.2012.10.150

[4] Energy Commision. "Malaysia Energy Statistics Handbook 2019." 2019.

[5] Saidur, Rahman, Md Hasanuzzaman, S. Yogeswaran, H. A. Mohammed, and M. S. Hossain. "An end-use energy analysis in a Malaysian public hospital." Energy 35, no. 12 (2010): 4780-4785. https://doi.org/10.1016/i.energy.2010.09.012

[6] Energy Commision. "Performance \& Statistical Information on the Malaysian Electricity Supply Industry 2018." 2018.

[7] Moghimi, Saeid, S. Mat, C. H. Lim, A. Zaharim, and K. Sopian. "Building energy index (BEI) in large scale hospital: case study of Malaysia." In 4th WSEAS International Conference on Recent Reseaches in Geography Geology, Energy, Environment and Biomedicine, Corfu Island, Greece. 2011.

[8] Teske, Sven, Thomas Pregger, Sonja Simon, Tobias Naegler, Wina Graus, and Christine Lins. "Energy [R] evolution 2010-a sustainable world energy outlook." Energy Efficiency 4, no. $3 \quad$ (2011): $409-433$. https://doi.org/10.1007/s12053-010-9098-y

[9] Moghimi, S., F. Azizpour, S. Mat, C. H. Lim, E. Salleh, and K. Sopian. "Building energy index and end-use energy analysis in large-scale hospitals-case study in Malaysia." Energy efficiency 7, no. 2 (2014): 243-256. https://doi.org/10.1007/s12053-013-9221-y

[10] Ministry of Natural Resources and Environment Malaysia. "Malaysia: Second National Communication to the UNFCCC." 2012.

[11] Universiti Teknologi Malaysia, Kyoto Universiti Japan and National Institute for Environment Studies Japan. "Low Carbon Society Scenarios: Malaysia 2030." 2013.

[12] Kementerian Tenaga Teknologi Hijau dan Air Malaysia. "National Green Technology Policy." 2009.

[13] Malaysian Green Technology Corporation. "Guidelines for the Registration of MyHIJAU Mark Product." 2018.

[14] Gordo, E., A. Campos, and D. Coelho. "Energy efficiency in a hospital building case study: Hospitais da universidade de Coimbra." In Proceedings of the 2011 3rd International Youth Conference on Energetics (IYCE), pp. 1-6. IEEE, 2011.

[15] Buonomano, Annamaria, Francesco Calise, Gabriele Ferruzzi, and Adolfo Palombo. "Dynamic energy performance analysis: Case study for energy efficiency retrofits of hospital buildings." Energy 78 (2014): 555-572. https://doi.org/10.1016/i.energy.2014.10.042 
[16] S. Reddy, S. Sandbhor, and V. Dabir. "Bringing energy efficiency for hospital building through the conservative and preventive measures." Int. J. Innov. Technol. Explor. Eng. 8, no. 12 (2019): 3056-3060. https://doi.org/10.35940/ijitee.L2470.1081219

[17] Dezfouli, M. M. S., Mohd Zaid Abu Yazid, Ahmad Zakaria, Syed Faiz Ahmed, Athar Ali, and S. Moghimi. "Application of high efficiency motors in HVAC system for energy saving purpose." In 2018 IEEE International Conference on Innovative Research and Development (ICIRD), pp. 1-5. IEEE, 2018. https://doi.org/10.1109/ICIRD.2018.8376309

[18] Teke, Ahmet, and Oğuzhan Timur. "Assessing the energy efficiency improvement potentials of HVAC systems considering economic and environmental aspects at the hospitals." Renewable and Sustainable Energy Reviews 33 (2014): 224-235. https://doi.org/10.1016/i.rser.2014.02.002

[19] Gatea, Anwer, Mohd Faizal Mohideen Batcha, and Juntakan Taweekun. "Energy efficiency and thermal comfort in hospital buildings: A review." International Journal of Integrated Engineering 12, no. 3 (2020): 33-41.

[20] Prasetyadi, A., and A. Koonsrisuk. "Minimization of Energy and Water Cost for the Main Building of Suranaree University of Technology Hospital (SUTH)." In IOP Conference Series: Materials Science and Engineering, vol. 886, no. 1, p. 012039. IOP Publishing, 2020. https://doi.org/10.1088/1757-899X/886/1/012039

[21] U.S. Department of Energy. "Energy-efficient hospital lighting strategies pay off quickly." 2011.

[22] Alzubaidi, Safaa, and Prashant Kumar Soori. "Energy efficient lighting system design for hospitals diagnostic and treatment room-a case study." Journal of Light \& Visual Environment 36, no. 1 (2012): 23-31. https://doi.org/10.2150/jlve.36.23

[23] Radwan, Ahmed F., Ahmed A. Hanafy, Mohamed Elhelw, and Abd El-Hamid A. El-Sayed. "Retrofitting of existing buildings to achieve better energy-efficiency in commercial building case study: Hospital in Egypt." Alexandria engineering journal 55, no. 4 (2016): 3061-3071. https://doi.org/10.1016/i.aej.2016.08.005

[24] Patil, Govind Shripad, and Vedavyasa Kamath. "Energy efficient LED lighting scheme for a hospital segment." In 2017 International Conference on Intelligent Computing, Instrumentation and Control Technologies (ICICICT), pp. 1485-1489. IEEE, 2017. https://doi.org/10.1109/ICICICT1.2017.8342789

[25] William, M., A. El-Haridi, A. Hanafy, and A. El-Sayed. "Assessing the energy efficiency and environmental impact of an egyptian hospital building." In IOP Conference Series: Earth and Environmental Science, vol. 397, no. 1, p. 012006. IOP Publishing, 2019. https://doi.org/10.1088/1755-1315/397/1/012006

[26] Suszanowicz, D., and P. Ratuszny. "Energy efficiency improvement in hospital buildings, based on the example of a selected type of hospital facility in Poland." In IOP Conference Series: Materials Science and Engineering, vol. 564, no. 1, p. 012129. IOP Publishing, 2019. https://doi.org/10.1088/1757-899X/564/1/012129

[27] Hyseni, Driton, Done J. Tashevski, Risto V. Filkoski, and Igor K. Shesho. "Energy efficiency in complex buildings." In IOP Conference Series: Earth and Environmental Science, vol. 410, no. 1, p. 012024. IOP Publishing, 2020. https://doi.org/10.1088/1755-1315/410/1/012024

[28] Cesari, Silvia, Paolo Valdiserri, Maddalena Coccagna, and Sante Mazzacane. "The energy saving potential of wide windows in hospital patient rooms, optimizing the type of glazing and lighting control strategy under different climatic conditions." Energies 13, no. 8 (2020): 2116. https://doi.org/10.3390/en13082116

[29] Fraile, Juan-Carlos, Julio San-José, and Ana González-Alonso. "A boiler room in a 600-bed hospital complex: study, analysis, and implementation of energy efficiency improvements." Energies 7, no. 5 (2014): 3282-3303. https://doi.org/10.3390/en7053282

[30] García-Sanz-Calcedo, Justo, Awf Al-Kassir, and Talal Yusaf. "Economic and environmental impact of energy saving in healthcare buildings." Applied Sciences 8, no. 3 (2018): 440. https://doi.org/10.3390/app8030440

[31] Nourdine, Brahim, and Abdallah Saad. "Energy Efficiency and Importance of Energy Monitoring System in Moroccan Hospitals." In 2019 7th International Renewable and Sustainable Energy Conference (IRSEC), pp. 1-7. IEEE, 2019. https://doi.org/10.1109/IRSEC48032.2019.9078270

[32] García-Sanz-Calcedo, J., and M. Gómez-Chaparro. "Quantitative analysis of the impact of maintenance management on the energy consumption of a hospital in Extremadura (Spain)." Sustainable cities and society 30 (2017): 217-222. https://doi.org/10.1016/i.scs.2017.01.019

[33] Energy Commision. "Efficient Management of Electrical Energy Regulations 2008." 2008.

[34] Energy Commission. "Electrical Energy Audit Guidelines." 2016.

[35] Ludin, Norasikin Ahmad, Mirratul Mukminah Junedi, Nurfarhana Alyssa Ahmad Affandi, Mohd Adib Ibrahim, Kamaruzzaman Sopian, Mohd Asri Mat Teridi, Suhaila Sepeai, Mohd Sukor Su'ait, and Lim Chin Haw. "Energy efficiency action plan for a public hospital in Malaysia." Alam Cipta 12, no. Special Issue 1 (2019): 73-79.

[36] Thinate, Nattanee, Wongkot Wongsapai, and Det Damrongsak. "Energy performance study in Thailand hospital building." Energy Procedia 141 (2017): 255-259. https://doi.org/10.1016/j.egypro.2017.11.102

[37] Damrongsak, Det, Wongkot Wongsapai, and Nattanee Thinate. "Factor impacts and target setting of energy consumption in Thailand's hospital building." Chemical Engineering Transactions 70 (2018): 1585-1590.

[38] Tenaga Nasional Berhad. "Tariff Book." 2006. 
[39] Department of Standards Malaysia. "Malaysian Standard MS 1525:2014 Code of Practice on Energy Efficiency and Use of Renewable Energy for Non-residential Buildings (Second Revision)." 2014.

[40] Ab Ghani, Sharin, and Idris Mohd Yusoff. "Comparative Study of Residential Lighting Technologies." Journal of Advanced Research in Applied Sciences and Engineering Technology 14, no. 1 (2019): 8-20.

[41] Malaysian Green Technology and Climate Change Centre. "Garis Panduan Perolehan Hijau Kerajaan (GGP) 3.0." 2020. 